\title{
外来がん化学療法患者を対象とした 苦痛のスクリーニングの導入
} 一苦痛対応に必要なりソースに関する分析一

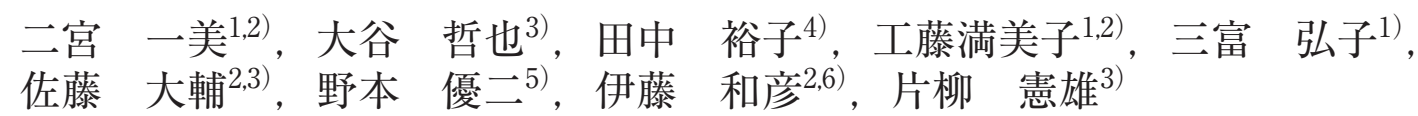

1）新潟市民病院 看護部，2）新潟市民病院 患者総合支援センター，3）新潟市民病院 消化器外科,

4）新潟市民病院 薬剤部, 5）新潟市民病院 緩和ケア内科, 6）新潟市民病院 呼吸器内科

がんの苦痛スクリーニングで対応に必要なリソースを求め, 円滑な緩和ケア提供の条件を求めることを目的とした. 2017 年 3 月までの 2 年間の外来がん化学療法 1479 例を対象とし STAS-」症状版でスコア 2 以上を有症状とし た. 有症状は 181 例(12.2\%), リソースは 12 職種, 延ベリソース数は 288 件だった. 対応は認定看護師·薬剂師 による「直接介入」153 件,「主治医対応」98 件、「その他リソースの対応」37 件だった. 不安等の精神症状は「直接介 入」(61 件, 39.9\%)が「主治医対応」(10 件, 10.2\%)より有意に高頻度だった $(p<0.0001)$. 身体症状への対応は「主 治医対応」(88 件, 89.8\%)が「直接介入」(92 件，60.1\%)より有意に高頻度であった $(p<0.0001)$. がんの苦痛対 応には多くのリソースが必要で, 認定看護師·薬剤師の直接介入と患者振り分けが緩和ケアデリバリーに有用である. Palliat Care Res 2019; 14(1): 15-21

Key words: 苦痛のスクリーニング, STAS-J, 緩和ケアデリバリー, 外来がん化学療法

\section{緒 言}

2014 年 1 月に「がん診療連携拠点病院等の整備に関 する指針 $\rfloor^{1)}$ が通知され，がん患者に対する苦痛のスク リーニングの実施は，がん診療連携拠点病院では必須 となった。 その内容は, (1)がん患者の身体的, 精神的, 社会的苦痛等のスクリーニングを診断時から外来およ び病棟にて行うこと, (2)院内で一貫したスクリーニン グ手法を活用すること, (3)緩和ケアチームと連携し, スクリーニングされた苦痛を迅速かつ適切に緩和する 体制を整備することである。しかし，スクリーニング 方法の選択および運用や, 有症状患者への対応につい ては詳しく定められているわけではない.

本邦では 2007 年頃から複数の病院でがん患者に対 する苦痛のスクリーニングの導入が試験的に行われて いた2．2008 年には，緩和ケアスクリーニングを含め

受付日 2018 年 9 月 21 日/改訂日 2018 年 12 月 13 日/受理日 2018 年 12 月 21 日

\section{Corresponding Author：大谷哲也}

新潟市民病院 消化器外科

于 950-1197 新潟県新潟市中央区鐘木 463 番地 7

TEL 025-251-5151 FAX 025-281-5187

E-mail: otani426@gmail.com
た緩和ケア研究として，4地域を対象とした地域介入 による前後比較研究である OPTIM-study ${ }^{3)}$ が行われた。 OPTIM-study では「生活のしやすさに関する質問票」を スクリーニングッールとして使用し，患者の身体症 状, 精神症状, 心理・社会的なニードが包括的に評価 された。その結果導入効果として多職種チームがかか われるきっかけになるとの意見の一方で, 運用が難し く工夫が必要である, ツールを利用する時間や人員が いないとの意見がみられた4)。2015 年に実施された苦 痛のスクリーニングの実態調査 ${ }^{5)}$ では, 379 施設でスク リーニングの導入を行っていたが, 入院・外来両方と もに実施している施設は $67 \%$ たった。 また，外来のす べての部署でスクリーニングを実施していたのは $10 \%$ と低率だった ${ }^{5)}$ 。この実態調査から日本ではがん 患者に対する苦痛のスクリーニングはいまだ黎明期の 段階で，入院患者より外来患者の実施および対応が難 しいことが予想される，有症状患者に対するスクリー ニングは実施するのみでは患者の症状改善にはつなが らないことはすでに報告されており ${ }^{6 \sim 8)}$ ， スクリーニ ング結果の記録およびリソースの分析, 症状改善の有 無まで含めた結果分析まで実施して初めて有用か否か 判定が可能となる9．２．そのため苦痛のスクリーニング を導入しても，苦痛への対応は多岐にわたるため，対 応を効率的に実施するには施設への負担が重いこ 
表 1 STAS-J症状版 : グレード別症状

\begin{tabular}{ll}
\hline グレード & \multicolumn{1}{c}{ 症状 } \\
\hline 0 & なし \\
1 & $\begin{array}{l}\text { 時折, 断続的, 患者は今以上の治療を必要としない(現在の治療に満足してい } \\
\text { る, 介入不要) }\end{array}$ \\
& 中等度, 時に悪い日もあり, 日常生活動作に支障をきたすことがある(薬の調 \\
& 節や何らかの処置が必要だがひどい症状ではない) \\
3 & しばしばひどい症状があり日常生活動作や集中力に著しく支障をきたす \\
4 & ひどい症状が持続的にある
\end{tabular}

$と^{6,10)}$ が指摘されている。緩和ケアにおける苦痛のス クリーニング導入効果に対する総説 ${ }^{7)}$ では, 有用で あったと結論した研究は $42 \%$ のであった。これまで 苦痛のスクリーニングを導入した施設において症状の 頻度の研究は散見される ${ }^{11 \sim 13)}$ が, 症状に対処するため に必要な人的資源すなわちリソースに関する分析評価 についての研究報告はこれまでない.

本研究の目的は, 外来がん化学療法患者の苦痛のス クリーニング後の症状改善のための対応に必要なり ソースを明らかにすることで, 効率的なスクリーニン グ体制構築における問題点を指摘し，スクリーニング から有用な緩和ケアの提供を行う条件を提示すること である

\section{方 法}

\section{研究対象}

2015 年 4 月から 2017 年 3 月までに新潟市民病院の 外来化学療法室でがん化学療法が行われた患者のうち 局所進行がんまたは再発がん症例を対象とした。

\section{評価方法}

全患者に the Japanese version of the Support Team Assessment Schedule (STAS-J) 症状版 ${ }^{14)}$ でスクリーニン グを行なった。スクリーニングは局所進行がんまたは 再発がんの患者に対して化学療法を初回に実施する時 および薬剤の変更時に行われた。 スクリーニングは外 来化学療法室でがん性疼痛看護認定看護師およびがん 薬物療法・緩和薬物療法認定薬剤師により聞き取り形 式により行われた。STAS-J 症状版 ${ }^{14)}$ では，以下の症状 別にスコアで評価が行われる。すなわち，その症状 は, 疼痛, しびれ，全身倦㤐感，呼吸困難，せき，た ん, 嘔気, 嘔吐, 腹満, 口掲, 食欲不振, 便秘, 下痢, 尿閉, 失禁, 発熱, ねむけ, 不眠, 抑うつ, 世ん妄, 不安, 浮腫, その他の 23 項目である. STAS-J 症状版 ${ }^{14)}$ ではスコアは 0 ～９５段階に分類され，0 と 1 は介入 不要の状態で, 2 以上が要介入と判定される (表 1 )。本 研究ではスコア 2 以上を苦痛ありと判定した。苦痛あ りの患者は症状別に分類し, 利用したリソースと対処
を記載した。本研究開始前に, 認定看護師・薬剂師, 看護師全員にSTAS-J 症状版のスコアリングの方法, 運 用方法について説明した。スクリーニング結果は，電 子カルテの台帳に直ちに記載された。苦痛ありの場合 は, 電子カルテにその内容と対処が記載され, 主治医 等と情報が共有された。リソースとは, 対応に必要で あった職種や診療グループと定義され, 苦痛改善に必 要であった職種が記録された。疼痛，しびれ，全身倦 总感，呼吸困難，せき，たん，嘔気，嘔吐，腹満，口 掲, 食欲不振, 便秘, 下痢, 尿閉, 失禁, 発熱, ねむ け, 不眠, 抑うつ, せん妄, 不安, 浮腫, その他の症 状のうち不眠, 抑うつ, せん妄, 不安を「精神症状」, それ以外の症状を「身体症状」と 2 群に分類した。

スクリーニングで苦痛ありと診断された場合には以 下の 3 種類の対応: 「直接介入」, 「主治医対応」, 「その 他リソースの対応」が行われた。「直接介入」とは, スク リーニングを行った認定看護師・薬剤師が直接患者に 支援を行った場合で，患者に対する指導や傾聴および 継続支援と定義され，他のリソースへ対応を依頼し対 応した場合は含まないこととした。「主治医対応」とは 薬剂調整, 病状変化の説明および対応を行った場合, あるいは認定看護師・薬剤師が主治医に相談あるいは 診療を依頼し主治医が対応した行為と定義され，他科 の医師の診察依頼などは含まないこととした。「その 他リソースの対応」とは「直接介入」と「主治医対応」を 除いた対応とし, 他科医師の対応, 主治医 - 認定看護 師・薬剤師以外のリソースが対応した場合, 緩和ケア チームに依頼し対応した場合と定義した。緩和ケア チームで対応とは，主治医や認定看護師・薬剤師等の 個人では解決困難で, 緩和ケア内科医師, 認定看護 師・薬剤師, 医療福祉相談員, 臨床心理士がチームと して共同で対応した場合とした。各症状別に対応リ ソースを分析し，がん患者の症状別に対応症例数を記 載した。対応はスクリーニング実施日に行われた。

\section{分析方法}

統計学的解析には R(Version 2.2, Vienna, Austria)を用 いた，有意差検定は $\chi^{2}$ 検定が行われ，有意水準は $5 \%$ とし両側検定を行った。 


\section{倫理的配慮}

本研究は新潟市民病院臨床倫理部会の承認を得て行 われた

\section{結 果}

2015 年 4 月から 2017 年 3 月までに外来化学療法室 でがん化学療法が行われた患者は 1479 例で, 男性 630 例 女性 849 例, 平均年齢 62.3 歳 (22〜93 歳)だった

\section{表 2 対象症例の内訳}

\begin{tabular}{lrr}
\hline 項目 & 症例数 & \multicolumn{1}{c}{$\%$} \\
\hline 性別 & & \\
男 & 630 & 42.6 \\
女 & 849 & 57.4 \\
原疾患 & & \\
$\quad$ 肺 & 65 & 4.4 \\
結腸·直腸 & 329 & 22.2 \\
胃 & 189 & 12.8 \\
肝臟 & 7 & 0.5 \\
胆囊·胆管·膵臓·十二指腸 & 121 & 8.2 \\
食道 & 28 & 1.9 \\
乳腺 & 540 & 36.5 \\
子宮·卵巣 & 23 & 1.6 \\
泌尿器 & 26 & 1.8 \\
血液 & 143 & 9.7 \\
頭頸部 & 3 & 0.2 \\
䐉 & 2 & 0.1 \\
原発不明 & 3 & 0.2 \\
\hline
\end{tabular}

（表 2). 外来化学療法患者で苦痛のスクリーニングを 受ける以前に 48 例がすでに緩和ケア内科を紹介され 受診していた，苦痛のスクリーニングは1479例に行わ れ，がんの種類別内訳を表 2 に示した。このうち苦痛 ありと判断された症例は 181 例 (12.2\%) だった。その 内訳を症状別にみると, 23 項目のうち 15 項目で苦痛 ありが認められた(表3)。認定看護師・薬剂師対応に よる「直接介入」は 153 件, 「主治医対応」は 98 件, 「そ の他リソースの対応」は37件だった。「その他リソース の対応」の 37 件はすべて認定看護師・薬剤師が主治医 に対応を提案したもので，その対応内訳は，他科また は緩和ケア科の医師への診察を提案し相談し対応した 12 件，緩和ケアチームに対応依頼した 15 件，医療福 祉相談員に対応依頼した 7 件, 医療心理士に対応依頼 した 2 件，がん患者会 1 件だった(表 3 ).

苦痛ありと評価された患者への対応で必要となった リソースは 12 職種またはチームで, 認定看護師, 認定 薬剂師, 主治医, 眼科医師, 歯科医師, 皮膚科医師, 整形外科医師, 緩和ケア内科医師, 緩和ケアチーム, 医療福祉相談員, 臨床心理士, がん患者会だった。 ス クリーニング後に一症状に対して複数の対応が必要と なった場合があり，症状改善のために必要となった対 応別延べ総数は表 3 に示した。有症状 181 例の対応延 ベリソース数は 288 件で, 1 例あたり平均 1.6 件のリ ソースが必要だった。有症状例の精神症状への対応 は, 認定看護師・薬剤師対応による「直接介入」(61 件, $39.9 \%)$ が「主治医対応」(10 件， 10.2\%)より有意に高頻 度だった $(\mathrm{p}<0.0001)$ (表 4)。有症状の身体症状への対

表 3 スクリーニング後に症状改善のために必要となったリソース別延べ対応数

\begin{tabular}{|c|c|c|c|c|c|c|c|c|c|c|c|c|}
\hline \multirow[b]{2}{*}{ 症状 } & \multirow{2}{*}{$\begin{array}{l}\text { 症例 } \\
\text { 数 }\end{array}$} & \multirow[b]{2}{*}{$\%$} & \multirow{2}{*}{ リ $\underset{\substack{\text { ソ延ベース } \\
\text { 数 }}}{ }$} & \multicolumn{9}{|c|}{ リソース別対応延べ数 } \\
\hline & & & & $\begin{array}{l}\text { 主治医 } \\
\text { 対応 }\end{array}$ & $\begin{array}{l}\text { 他科の } \\
\text { 医師 }\end{array}$ & $\begin{array}{l}\text { 緩和ヶア } \\
\text { 内科医師 }\end{array}$ & $\begin{array}{l}\text { 認定 } \\
\text { 着護師 }\end{array}$ & $\begin{array}{l}\text { 認定 } \\
\text { 薬剤師 }\end{array}$ & $\begin{array}{l}\text { 緩和ケア } \\
\text { チーム }\end{array}$ & $\begin{array}{c}\text { 医療福祉 } \\
\text { 相談員 }\end{array}$ & $\begin{array}{l}\text { 臨床 } \\
\text { 心理士 }\end{array}$ & $\begin{array}{l}\text { がん } \\
\text { 患者会 }\end{array}$ \\
\hline 不安 & 49 & 27.1 & 72 & 6 & & 1 & 47 & 8 & 5 & 3 & 1 & 1 \\
\hline 疼痛 & 48 & 26.5 & 69 & 37 & 1 & 1 & 19 & 6 & 4 & 1 & & \\
\hline 嘔気 & 15 & 8.3 & 30 & 9 & & & 11 & 8 & 1 & 1 & & \\
\hline しびれ & 14 & 7.7 & 25 & 7 & 1 & 1 & 11 & 4 & 1 & & & \\
\hline 便秘 & 13 & 7.2 & 16 & 9 & & & 6 & 1 & & & & \\
\hline 口内炎 & 11 & 6.1 & 16 & 10 & 1 & & 4 & 1 & & & & \\
\hline 抑うつ & 7 & 3.9 & 13 & 3 & & & 6 & & 2 & 1 & 1 & \\
\hline 浮腫 & 3 & 1.7 & 8 & 1 & & 1 & 2 & 1 & 2 & 1 & & \\
\hline 下痢 & 3 & 1.7 & 7 & 2 & & & 3 & 2 & & & & \\
\hline 食欲不振 & 2 & 1.1 & 4 & 1 & & & 1 & 2 & & & & \\
\hline たん & 2 & 1.1 & 3 & 2 & & & 1 & & & & & \\
\hline 発熱 & 1 & 0.6 & 2 & 1 & & & 1 & & & & & \\
\hline 不眠 & 1 & 0.6 & 1 & 1 & & & & & & & & \\
\hline 嘔吐 & 1 & 0.6 & 1 & 1 & & & & & & & & \\
\hline 腹部膨満 & 1 & 0.6 & 3 & 1 & & & 1 & 1 & & & & \\
\hline その他 & 10 & 5.5 & 18 & 7 & 5 & & 4 & 2 & & & & \\
\hline 合計 & 181 & 100 & 288 & 98 & 8 & 4 & 117 & 36 & 15 & 7 & 2 & 1 \\
\hline
\end{tabular}


表 4 身体症状と精神症状に対するリソース別症例数

\begin{tabular}{|c|c|c|c|c|}
\hline \multirow[b]{2}{*}{ 症状 } & \multicolumn{3}{|c|}{ 症例数 } & \multirow[b]{2}{*}{ 計 } \\
\hline & $\begin{array}{c}\text { 直接介入 } \\
\text { (認定看護師, } \\
\text { 認定薬剤師が対応) }\end{array}$ & $\begin{array}{l}\text { 主治医 } \\
\text { 効応 }\end{array}$ & $\begin{array}{l}\text { その他職 } \\
\text { 種が対応 }\end{array}$ & \\
\hline 精神症状 & $61^{*}$ & 10 & 15 & 86 \\
\hline 身体症状 & 92 & $88^{* *}$ & 22 & 202 \\
\hline 計 & 153 & 98 & 37 & 288 \\
\hline
\end{tabular}

応は, 「主治医対応」(88 件， $89.8 \%)$ が認定看護師・薬 剤師対応による「直接介入」(92 件， $60.1 \%)$ 上り有意に 高頻度であった $(\mathrm{p}<0.0001)$ (表 4)，緩和ケアチームで 対応は 15 件 (5.2\%)で, 対応が必要だった症状の内訳 は不安 5 件, 疼痛 4 件, 抑うつ 2 件, しびれ 1 件, 嘔 気 1 件, 浮腫 2 件だった。

\section{考 察}

2015 年 4 月からがん診療連携拠点病院では, 外来・ 入院患者のがん患者に対して苦痛のスクリーニングが 義務づけられた ${ }^{1)}$ 。奥山ら ${ }^{5)}$ は苦痛のスクリーニング の実態を把握する目的でがん診療拠点病院 422 施設に 全国アンケート調査を実施し, 回答施設の $88 \%$ は苦痛 のスクリーニングを導入しているとの結果だった。し かし， 60\%の施設でその後のフォローアップ体制が確 立されておらず，また $23 \%$ の施設はスクリーニング陽 性患者に対応するシステムが整っていなかった ${ }^{51}$ 。 ス クリーニングのための人員が不足していること，医療 者に時間がなく対応する体制を構築できないこと, 有 効な対応方法がみつからないことなどが原因として考 えられる。そこで本研究は，スクリーニング後の対応 に必要なリソースを明らかにすることで, 効率的なス クリーニング体制構築における問題点を指摘し, 緩和 ケア提供の条件を提示することを目的とした。本研究 の結果では, 外来がん化学療法患者の苦痛の症状は 15 症状と多岐にわたっていた。その症状に対処するため のリソースは 12 職種またはチームが必要で, 症状が複 雑である場合は緩和ケアチームが対応した。リソース は多職種が必要となり, 外来化学療法実施時に短時間 で問題点を効率よく把握し苦痛のスクリーニングおよ び対処と患者振り分けを迅速に行う必要がある。本研 究の結果では, 外来化学療法室で認定看護師・薬剤師 がスクリーニングを実施し, 患者に対する指導や傾聴 および継続支援を直接行うことで苦痛を有する患者へ の「直接介入」が可能となった。 また認定看護師・薬剤
師が他職種へのコンサルトを主治医に提案することに より円滑で効率的な苦痛緩和に対する早期介入が可能 となったと考えられた。リソースは多職種にわたり人 材の確保も重要となる。さらに対応のためのリソース へ振り分ける人材はきわめて重要で, 認定看護師・薬 剤師などのがんの教育を受けた人材の育成が必須であ ると考えられた。

本研究では, 認定看護師 ·薬剂師, 外来・病棟看護 師全員にSTAS-J 症状版の運用とスコアリングの方法 について説明し, 対応結果は電子カルテに記載され, 主治医と情報が共有された。緩和ケアに携わる多数の 職員で苦痛のスクリーニングの運用を理解することは 緩和ケアデリバリーの迅速性と情報共有の重要性を認 識することにつながると考えられる。すなわち効率的 な緩和ケア提供に必要な条件は, 簡便で信頼性のある スクリーニングツール, 認定看護師・薬荗師などの適 切なリソースに紹介できるがんの知識のある人材, 緩 和ケアに精通した多職種からなる豊富な人材, 多職種 間での情報共有が必要であると考えられる。OPTIMstudy $^{3)}$ においても，スクリーニング導入効果として多 職種チームがかかわれるきっかけになるとの意見の一 方で，運用が難しく工夫が必要である，ツールを利用 する時間や人員がいないとの意見がみられている. Mitchell ${ }^{15)}$ は緩和ケアデリバリー構築においては人材 育成とトレーニングがきわめて重要であると述べてい る。人材育成, システム運用の工夫，多職種での情報 共有により緩和ケアデリバリーはより効率的に実施が 可能であろう.

がん患者の身体的苦痛や精神的苦痛, 社会的苦痛等 のスクリーニングを診断時から行うこととされたが, 具体的なスクリーニングッールは指定されなかった。 スクリーニング使用に関する全国調査の結果5)では, 生活のしやすさに関する質問票, 独自ツール, STAS, つらさと支障の寒暖計の順に多く使用されていた。 STAS-J 症状版は多数の症状の苦痛の評価が可能であ るため ${ }^{16)}$ ，また簡便であるため，本研究ではスクリー ニングのツールとして選択された. Newell ら ${ }^{11)}$ は外来 で治療を受けている 201 人に苦痛の調査を行い, 15 の 身体症状を認め, 疲労・嘔気・食欲不振 - 嘔吐の順に 多かったと報告した。他の研究 ${ }^{12,17)}$ も同様に疲労・嘔 気・食欲不振・嘔吐が多く, STAS-J 症状版はそれら苦 痛が含まれており適切なツールであると判断し導入さ れた。一方で，STAS-J 症状版は身体・精神的苦痛の評 価が主たる目的であるため社会的苦痛等が十分に拾い 上げされない可能性がある。鈴木ら ${ }^{13)}$ は，455 例の新 規外来化学療法を対象とし, 延べ 2854 件の結果を分析 した結果，医療相談：0.2\%，在宅支援：0.4\%のみと少 数だったと報告した。当院ではがん患者相談室や医療 
福祉相談, さらに就職相談および斡旋まで提供されて 扔り, 患者・家族の社会的苦痛には対応が十分なされ ていると判断した，外来化学療法では判定に迅速性が 要求されるため, 認定看護師・薬郕師が効率的に遂行 可能であると考えスコアリング実施者とした。しか し, 限られた人数の認定看護師・薬剂師によるスク リーニングは限界があり, 患者の苦痛の早期発見には 外来化学療法室の看護師の協力も考慮すべきである.

リソースが至しい状況下ではスコア記入者は外来化学 療法室の看護師が行い, 苦痛改善を要する患者対応者 は認定看護師・薬剤師と役割分担することも考慮す心゙ きであろう。

がんの苦痛のスクリーニングの有用性を調査した総 説 ${ }^{15)}$ では, 14 の研究のうち有用性を見出せたのは 6 研 究であったと報告している，スクリーニングを実施す るのみでなく, 症状対応改善までのプロセスの重要性 と緩和ケアデリバリー構築をする人的, 時間的余裕が ないことも指摘している ${ }^{15)}$. 本研究でも苦痛ありの症 例は 181 例， $12.2 \%$ だったが，それに対して 12 職種の リソースが必要でさらに 1 症例に対し複数の職種が必 要で, 対応したリソース総数は 288 件だった。 多くの 専門家が苦痛の改善に必要となり, 問題解決の困難さ がうかがい知れる。しかし，それにもかかわらず苦痛 に対するスクリーニングは推奨されており，その有効 活用には現場のスタッフの教育が重要であるとしてい る ${ }^{15)}$. 本研究での外来化学療法患者で苦痛ありは $12.2 \%$ で，一方 Morita ら2) $^{12}$ 苦痛ありが $18 \%$ たったと 報告した，苦痛ありが本研究より高頻度なのは対象症 例が少ないための影響と考えられるが，口腔ケアの問 題，不眠，方針決定の情報に関する不安が多かったと 報告した. 本研究ではもっとも多い症状は不安の 49 例 で, 疼痛の 45 例が 2 番目に多い症状であった（表 3 ). 対応方法でみると, 不安, 抑うつなどの精神症状は認 定看護師・薬剂師による「直接介入」が「主治医対応」よ り有意に多く, 一方, 疼痛, しびれなどの身体症状は 「主治医対応」が「直接介入」より有意に多かった（表 4)。不安，抑うつなどの精神症状は認定看護師や認定 薬剂師が患者とコミュニケーションを行うことで症状 改善が可能な場合があり, その結果「直接介入」が可能 となり有意に多かったのであろう，外来という限られ た時間では短時間での患者からの情報の収集が必要で あり, がん化学療法患者に対する認定看護師と認定薬 剽師によるスクリーニングは，その場での問題解決が 可能となるのみならず，他の専門職への振り分けを行 うという責務を担っている。精神的苦痛の評価には, 「つらさと支障の寒暖計」18) や PHQ-9 日本語版「こころ とからだの質問票」19) の使用でうつ病や適応障害の診 断には効率的で有用であることが報告されている。通
常の苦痛のスクリーニングに加えて「つらさと支障の 寒暖計」のスクリーニングを加えると精神疾患の発見 率が上がることが報告20)されている. STAS-J 症状版と 精神疾患のスクリーニングッールの併用は, より正確 な精神的苦痛の診断に有用となる可能性がある.

がん患者に対して，専門的緩和ケアが介入すべき適 切な時期はいまだ明らかでない. Hui ら ${ }^{211}$ は緩和ケア 介入のタイミングは, がん薬物療法二次治療の効果が ない時であるとし，予後の短い悪性腫瘍の場合は診断 時からの緩和ケア介入が必要であると報告した。さら に施設ごとに緩和ケア提供体制やリソースが変わるた めに, 医療提供体制の整備が必要であると述べてい る22)、日本ではすべてのがん患者に緩和ケアが行われ ることとなった一方で, 米国臨床腫瘍学会22)では 2017 年に, 進行がん患者は積極的な抗がん治療と並行して 早期の段階から多職種で構成された緩和ケアチームに 紹介されるべきであるとした。すなわち日本ではがん 患者すべてが対象であり, 米国臨床腫瘍学会 ${ }^{22}$ では進 行がんのみを早期の緩和ケアの対象とした点が相違点 である. 本研究の対象患者は外来で化学療法を実施す る患者であり, 局所進行がんまたは再発がんが対象で ある。事前に緩和ケア内科に紹介されていた患者も扔 り，すでに苦痛緩和がなされていた可能性があり，本 研究の苦痛のスクリーニング陽性率が低下したかもし れない. しかし，それにもかかわらず必要なリソース は12職種またはチームと多いため, 外来での効率的な 運用を構築しておく必要があると考えられた。苦痛の スクリーニングを有効に活用するには，スクリーニン グ実施者により各患者に必要なケアを選別し、リソー スへ効率的にデリバリーすることが重要である。その ためにはがんの知識が豊富である認定看護師や認定薬 剤師などの人材育成が重要で, それらの職種により迅 速な患者の振り分けが可能となり，有効な緩和ケアデ リバリーが行えると考えられた。

\section{研究の限界}

本研究は単一施設での研究で, 症例分布に偏りがあ る可能性がある。またスクリーニング実施者が 2 人の みであり，実施者の特性が研究結果に影響した可能性 がある、単一施設の研究であるため, リソースは当院 にある設備や人員しか使用することができないことか ら，偏りが生じている可能性がある。

\section{結 論}

本研究の結果では, 外来でのがん化学療法患者に対 する苦痛のスクリーニング陽性率は 181 例 (12.2\%) だった. 有症状 181 例に対する延べ対応数は 288 件で, 1 例あたり平均 1.6 件のリソースが必要だった。苦痛の 
うち疼痛やしびれなどの身体症状は「主治医対応」が認 定，看護師・薬剂師の「直接介入」より有意に多かっ た。一方, 抑うつや不安などの精神症状は認定看護 師・認定薬剤師による「直接介入」が「主治医対応」より 有意に多かった。苦痛の緩和に必要となったリソース は12職種またはチームだった。がんの苦痛対応には多 くのリソースが必要で, これらリソースへ提供を依頼 する認定看護師や認定薬郕師の役割は, 外来という限 られた時間の中で円滑かつ迅速な緩和ケアデリバリー を行ううえで重要であると考えられた。

謝辞 本研究にご協力していただいた対象者の皆様，外来化 学療法室のスタッフの皆様に感謝申し上げます。

また, 本研究は, 2017 年, 第 55 回日本癌治療学会学術会議 (獚 浜)で発表した.

\section{著者の申告すべき利益相反なし}

二宮, 大谷は研究の構想㧤よびデザイン, 研究デー夕 の収集・分析・解釈, 原稿の起草に貢献; 田中, 工藤, 三富は研究デー夕の収集・分析・解釈，原稿の重要な 知的内容に関わる批判的な推敲に貢献; 佐藤, 野本,

伊藤, 片柳は研究デー夕の解釈, 原稿の重要な知的内 容に関わる批判的な推敲に貢献した。すべての著者は 投稿論文ならびに出版原稿の最終確認掞よび研究の説 明責任に同意した。

\section{文 献}

1）厚生労働省. がん診療連携拠点病院等の整備に関する 指針 2014 年 1 月 10 日 https://www.mhlw.go.jp/bunya/ kenkou/dl/gan_byoin_03.pdf (2018 年 7 月 1 日アクセス).

2）森田達也. 今後の課題と提言. 緩和ケアスクリーニング に関する事例集．青海社，東京，2016; 189-93.

3) Yamagishi A, Morita T, Miyashita M, et al. Palliative care in Japan: current status and a nationwide challenge to improve palliative care by the cancer control act and the outreach palliative care trial of integrated regional model (OPTIM) study. Am J Hosp Palliat Care 2008; 25: 412-8.

4）木澤義之, 梅田 恵, 新城拓也, 他. 地域で統一した緩 和ケアマニュアル・パンフレット・評価シートの評価： OPTIM-study. Palliat Care Res 2012; 7: 172-84.

5）奥山 徹, 明智龍男，木澤義之，他. A1 緩和ケアの現 状に関する全国実態調查 全国の動向。緩和ケアスク リーニングに関する事例集．青海社，東京，2016; 4-22.

6）上元洵子, 奥山 徹, 森田達也. A2 緩和ケアの現状に 関する全国実態調查 緩和ケアスクリーニングに関す る各施設の現状と考え, 緩和ケアスクリーニングに関 する事例集．青海社，東京，2016; 23-8.

7) Carlson LE, Waller A, Mitchell AJ. Screening for distress and unmet needs in patients with cancer: review and recommendations. J Clin Oncol 2012; 30: 1160-77.
8) Hollingworth W, Metcalfe C, Mancero S, et al. Are needs assessments cost effective in reducing distress among patients with cancer? A randomized controlled trial using the Distress Thermometer and Problem List. J Clin Oncol 2013; 31 : 3631-8.

9) Lazenby M, Tan H, Pasacreta N, et al. The five steps of comprehensive psychosocial distress screening. Curr Oncol Rep 2015; 17: 447.

10) Mitchell AJ, Lord K, Slattery J, et al. How feasible is implementation of distress screening by cancer clinicians in routine clinical care? Cancer 2012; 118: 6260-9.

11) Newell S, Sanson-Fisher RW, Grigis A, et al. The physical and psycho-social experiences of patients attending an outpatient medical oncology department: a cross-sectional study. Eur J Cancer Care 1999: 8: 73-82.

12) Morita $T$, Fujimoto K, Namba M, et al. Palliative care needs of cancer outpatients receiving chemotherapy: an audit of a clinical screening project. Support Care Cancer 2008: 16: 101-7.

13）鈴木留美, 山口 崇, 藤本亘史, 他.「生活のしやすさ 質問票第 3 版」を用いた外来化学療法患者の症状頻度 · ニードおよび専門サービス相談希望の調査. 緩和ケア 2011; 21: 542-8.

14）STAS ワーキング・グループ 編 STAS-J(STAS 日本語 版) スコアリングマニュアル一緩和ケアにおけるクリニ カル・オーディットのために一, 第 3 版. 日本ホスピ ス・緩和ケア研究振興財団.

15) Mitchell AJ. Screening for cancer-related distress: when is implementation successful and when is it unsuccessful? Acta Oncol 2013; 52: 216-24.

16) Miyashita M, Yasuda M, Baba R, et al. Inter-rater reliability of proxy simple symptom assessment scale between physician and nurse: a hospital-based palliative care team setting. Eur J Cancer Care 2010; 19: 124-30.

17) Yamagishi A, Morita $T$, Miyashita M, et al. Symptom prevalence and longitudinal follow-up in cancer outpatients receiving chemotherapy. J Pain Symptom Manage 2009; 37: 82330.

18) Akizuki N, Yamawaki S, Akechi T, et al. Development of an Impact Thermometer for use in combination with the Distress Thermometer as a brief screening tool for adjustment disorders and/or major depression in cancer patients. J Pain Symptom Manage 2005; 29: 91-9.

19）高木健司, 高塚直能, 佐々木翼, 他. 緩和ケア病棟にお ける抑うつスクリーニングッールとしての PHQ-9 日本 語版「こころとからだの質問票」の有用性について—精 神科常勤医師のいない病棟への導入一. Palliat Care Res 2018; 13: 69-75.

20) Shimizu K, Akechi T, Okamura M, et al. Usefulness of the nurse-assisted screening and physical referral program. Cancer 2005; 103: 1945-56.

21) Hui D, Mori M, Watanabe SM et al. Referral criteria for outpatient specialty palliative cancer care: an international consensus. Lancet Oncol 2016; 17: e552-9.

22) Ferrell BR, Temel JS, Temin S, et al. Integration of palliative care into standard oncology care: American society of clinical oncology clinical practice guideline update. J Clin Oncol 2017; 35: 96-112. 


\title{
Original Research
}

\section{Alleviating Distress in Outpatients Undergoing Chemotherapy: Analysis of Resources Required for Palliative Cancer Care Delivery}

\author{
Hitomi Ninomiya, ${ }^{1,2)}$ Tetsuya Otani ${ }^{3)}$ Hiroko Tanaka, ${ }^{4)}$ Mamiko Kudo, ${ }^{1,2)}$ \\ Hiroko Mitomi, ${ }^{1)}$ Daisuke Sato, ${ }^{2,3)}$ Yuji Nomoto, ${ }^{5)}$ Kazuhiko Ito, ${ }^{2,6)}$ \\ and Norio Katayanagi ${ }^{3)}$ \\ 1) Division of Nursing, Niigata City General Hospital, \\ 2) Section of Patient and Family Support Center, Niigata City General Hospital, \\ 3) Department of Digestive Surgery, Niigata City General Hospital, \\ 4) Department of Pharmacy, Niigata City General Hospital, \\ 5) Department of Palliative Care Medicine, Niigata City General Hospital, \\ 6) Department of Respiratory Medicine, Niigata City General Hospital
}

This study aimed to clarify the resources required to relieve distress during palliative care delivery to cancer patients. Between April 2015 and March 2017, 1479 outpatients receiving chemotherapy for cancer were screened using the Japanese version of the Support Team Assessment Schedule (STAS-J). When the STAS-J result was 2 points and higher, the patient was considered positive for distress. A certified nurse or pharmacist performed STAS-J screening and, in cases where the patient exhibited distress, took steps to alleviate the problem themselves or consulted another resource. Distress was identified in 181 (12.2\%) of the 1479 patients. These 181 patients needed 288 resources. The resources used to alleviate distress were categorized as follows: direct support by certified nurse or pharmacist (153), consultation with the attending physician (98) and other (37). The required resource included the following twelve professionals: attending physician, ophthalmologist, dermatologist, dentist, orthopedic surgeon, palliative care physician, certified nurse, certified pharmacist, medical social worker, clinical psychologist, volunteers for cancer patients, and palliative care team. The frequency of the intervention by the certified nurse or pharmacist $(61,39.9 \%)$ in directly alleviating psychiatric distress was significantly higher than by consultation with the attending physician $(10,10.2 \%)(\mathrm{p}<0.0001)$. However, the frequency of consultation with the attending physician in alleviating physical distress $(88,89.8 \%)$ was significantly higher than that of the certified nurse or pharmacist $(92,60.1 \%)(\mathrm{p}<0.0001)$. We conclude that the certified nurse or pharmacist is important for the delivery of palliative cancer care, because they can directly provide relief from psychiatric distress.

Palliat Care Res 2019; 14(1): 15-21

Key words: screening for distress, STAS-J, palliative care delivery, outpatient cancer chemotherapy 